\title{
Hole Hopping through Tryptophan in Cytochrome P450
}

\author{
Maraia E. Ener, ${ }^{\dagger}$ Harry B. Gray,* and Jay R. Winkler*(1) \\ Beckman Institute, California Institute of Technology, Pasadena, California 91125, United States
}

\section{Supporting Information}

ABSTRACT: Electron-transfer kinetics have been measured in four conjugates of cytochrome P450 with surface-bound $\mathrm{Ru}$ photosensitizers. The conjugates are constructed with enzymes from Bacillus megaterium (CYP102A1) and Sulfolobus acidocaldarius (CYP119). A W96 residue lies in the path between $\mathrm{Ru}$ and the heme in CYP102A1, whereas H76 is present at the analogous location in CYP119. Two additional conjugates have been prepared with (CYP102A1)W96H and (CYP119)H76W mutant enzymes. Heme oxidation by photochemically generated $\mathrm{Ru}^{3+}$ leads to P450 compound II formation when a tryptophan residue is in the path between $\mathrm{Ru}$ and the heme; no heme

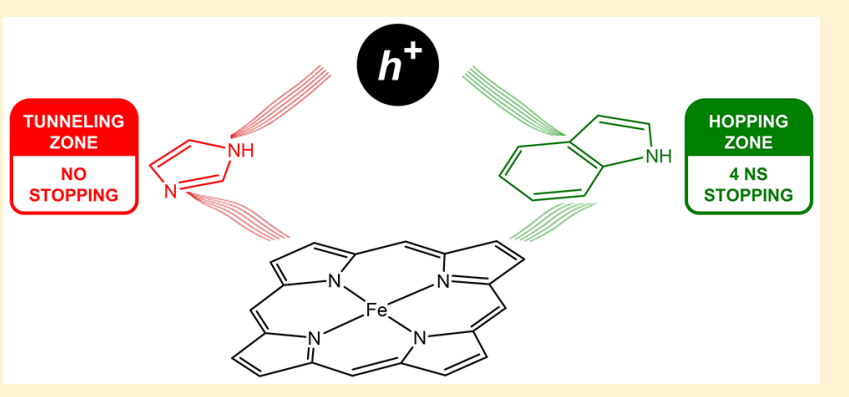
oxidation is observed when histidine occupies this position. The data indicate that heme oxidation proceeds via two-step tunneling through a tryptophan radical intermediate. In contrast, heme reduction by photochemically generated $\mathrm{Ru}^{+}$proceeds in a single electron tunneling step with closely similar rate constants for all four conjugates.

$\mathrm{M}$ ost biological redox transformations involve reagents with formal potentials in the $\pm 1 \mathrm{~V}$ vs NHE range. At the periphery of this potential window proteins present a decidedly unsymmetrical medium for electron transfer (ET). Whereas reduction of peptides and small aromatic groups only proceeds at potentials more negative than $-2.5 \mathrm{~V}$ vs $\mathrm{NHE}^{1-3}$ oneelectron oxidations of aromatic and sulfur-containing aminoacids, as well as the peptide backbone itself, can occur at potentials in the $1.0-1.5 \mathrm{~V}$ vs NHE range. ${ }^{4-11} \mathrm{We}$ anticipate, then, that proteins are superexchange mediators of ET in reactions of low-potential redox couples. In contrast, oxidized amino acid radicals are known to be essential participants in many high-potential enzymatic redox reactions, ${ }^{12-21}$ and structural evidence suggests that they may play a far greater role than previously recognized. ${ }^{22}$

Elucidating the roles of protein radicals, particularly those of the aromatic amino acids tryptophan (W) and tyrosine $(\mathrm{Y})$, in functional and protective pathways of high-potential enzymes continues to be an active area of research. ${ }^{22-25}$ The appearance of dioxygen in Earth's atmosphere promoted the evolution of a vast array of $\mathrm{O}_{2}$-utilizing enzymes that generate high-potential reactive intermediates capable of oxidizing tryptophan and tyrosine. The cytochromes $\mathrm{P} 450$ (CYP) are prominent representatives of this enzyme class, responsible for a broad spectrum of vital metabolic functions. ${ }^{26}$ The accepted enzymatic reaction cycle of cytochrome P450 involves two high-potential reactive intermediates (compounds I and II) that participate directly in reactions with substrates. ${ }^{27-32}$ In prior work, we demonstrated that compound II can be prepared in the heme domain of Bacillus megaterium P450 (CYP102A1) by oxidation of the $\mathrm{Fe}^{3+}$-heme with a surface-attached $\mathrm{Ru}$ (diimine $)_{3}{ }^{3+}$ complex $\left(E^{\circ}\left(\mathrm{Ru}^{3+/ 2+}\right) \approx 1.2 \mathrm{~V}\right.$ vs $\left.\mathrm{NHE}^{33,34}\right){ }^{35}$ We have extended this work to the archaeal Sulfolobus acidocaldarius P450 (CYP119). ${ }^{30}$ A key structural difference between the two enzymes is an aromatic side chain hydrogen bonded to one of the heme proprionates (W96 in CYP102A1; $\mathrm{H} 76$ in CYP119) (Figure 1). ${ }^{36,37}$ We find that an intervening
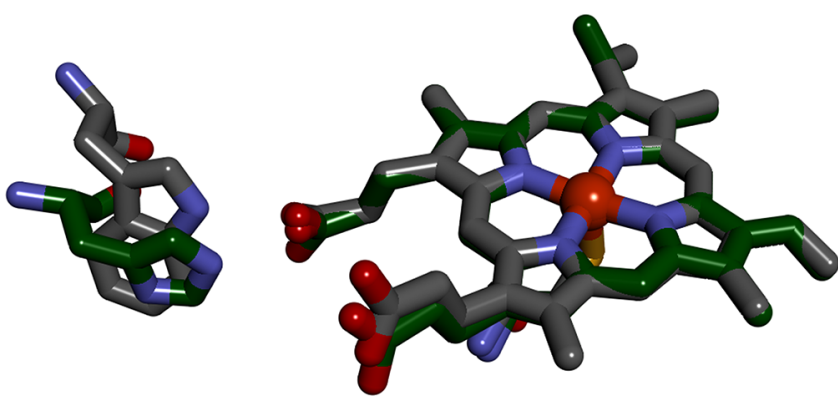

Figure 1. Overlay of the heme environments of CYP102A1 (gray carbon atoms) and CYP119 (green carbon atoms) illustrating the relative positions of W96 in CYP102A1 and H76 in CYP119. Atomic coordinates were taken from PDB IDs 2IJ2 (CYP102A1) ${ }^{34}$ and $11 \mathrm{OO} 7$ (CYP119). ${ }^{35}$

tryptophan residue (CYP102A1, W96; CYP119, H76W) is essential for promoting $\mathrm{Fe}^{3+}\left(\mathrm{OH}_{2}\right)$-heme oxidation by $\mathrm{Ru}$ (diimine) ${ }_{3}{ }^{3+}$ in both CYP102A1 and CYP119 but that these residues appear to play no analogous role in the reduction of $\mathrm{Fe}^{3+}\left(\mathrm{OH}_{2}\right)$-heme by $\mathrm{Ru}$ (diimine $)_{3}^{+}\left(E^{\circ}\left(\mathrm{Ru}^{2+/+}\right) \approx-1.3 \mathrm{~V}\right.$ vs $\left.\mathrm{NHE}^{33,34}\right)$.

Received: May 5, 2017

Revised: June 16, 2017

Published: July 9, 2017 


\section{EXPERIMENTAL PROCEDURES}

Materials. Buffer salts were obtained from J.T. Baker. 5Aminolevulenic acid and dithiothreitol were obtained from Sigma-Aldrich. $\left[\mathrm{Ru}\left(\mathrm{NH}_{3}\right)_{6}\right] \mathrm{Cl}_{3}$ was obtained from Strem Chemicals. All chemicals were used as received with no further purification. The ruthenium labeling reagent $\left(\left[\mathrm{Ru}\left(2,2^{\prime}\right.\right.\right.$ bipyridine $)_{2}$ (5-iodoacetamido 1,10-phenanthroline) $]^{2+}, \quad[\mathrm{Ru}$ $(\text { bpy })_{2}($ IAphen $\left.\left.)\right]^{2+}\right){ }^{38}$ model complex ([Ru(2,2'-bipyridine $)_{2}(5$-acetamido 1,10 -phenanthroline $\left.)\right]^{2+}, \quad[\mathrm{Ru}-$ (bpy) ${ }_{2}($ Aphen $\left.\left.)\right]^{2+}\right),{ }^{38}$ and $p$-methoxydimethylaniline ( $p$ MeODMA $)^{39}$ were synthesized according to published procedures. Solutions were prepared using $18 \mathrm{M} \Omega-\mathrm{cm}$ water unless otherwise noted. Mutagenesis primers were obtained from Operon.

Plasmid Preparation. The recombinant CYP102A1 (UniProt accession number P14779) heme domain, consisting of the first 463 residues with an N-terminal 6-histidine tag, was obtained courtesy of Professor Andrew Udit (Occidental College, Los Angeles California), within the pCWori ${ }^{+}$vector. Recombinant CYP119 (UniProt accession number Q55080) with an N-terminal 6-histidine tag was obtained courtesy of Professor Paul Ortiz de Montellano (University of California, San Francisco), also within the pCWori ${ }^{+}$vector. Qiagen QuikChange site-directed mutagenesis was used to generate the desired P450 mutants. Mutagenesis primers (forward, $5^{\prime}-3^{\prime}$ ) were CTAATTAAGAAGCAGCCGATGAATCACG (CYP102A1 C62A), CGATTGGTCTTAGCGGCTTTAAC (CYP102A1 C156S), GCTGGACGCATCAAAAAAATTGGTGCAAAGCGC (CYP102A1 K97C); GGACGCAT GAAAAAAA T CAT T GCAAAG C GCATAATAT C (CYP102A1 W96H); GATCCCCCTCTCCATTGTGAGTTAAGATCAATGTCAGC (CYP119 D77C), and CCTCAGATCCCCCTCTCTGGTGTGAGTTAAGATCAATGTC (CYP119 H76W).

Overexpression in E. coli. The P450 mutants CYP102A1-

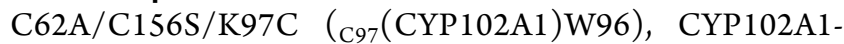
C62A/C156S/K97C/W96H ( $\left.{ }_{\mathrm{C} 97}(\mathrm{CYP} 102 \mathrm{A1}) \mathrm{W} 96 \mathrm{H}\right)$, CYP119-D77C (C77(CYP119)H76), and CYP119-D77C/ H76W ( $\left.{ }_{\text {C77 }}(\mathrm{CYP} 119) \mathrm{H} 76 \mathrm{~W}\right)$ were overexpressed in the BL21-DE3 strain of E. coli. Overnight cultures of LuriaBertani broth $(25 \mathrm{~mL})$ containing $100 \mu \mathrm{g} / \mathrm{mL}$ ampicillin and a single respective E. coli colony were incubated at $37{ }^{\circ} \mathrm{C}$ overnight, shaking at $180-200 \mathrm{rpm}$. Induction cultures of TB (1× TB for CYP102A1, $2 \times$ TB for CYP119) containing 200 $\mu \mathrm{g} / \mathrm{mL}$ ampicillin, $1 \mu \mathrm{M}$ thiamine, $0.4 \%$ glycerol, and $250 \mu \mathrm{L}$ of mineral supplements (stock solution $100 \mathrm{mM} \mathrm{FeCl}_{3}, 10 \mathrm{mM}$ $\mathrm{ZnCl}_{2}, 8.5 \mathrm{mM} \mathrm{CoCl}, 8.5 \mathrm{mM} \mathrm{Na} \mathrm{MoO}_{4}, 7 \mathrm{mM} \mathrm{CaCl}, 7.5$ $\mathrm{mM} \mathrm{CuCl} 2,8 \mathrm{mM} \mathrm{H}_{3} \mathrm{BO}_{3}$ ) were inoculated with the overnight culture and incubated at $37{ }^{\circ} \mathrm{C}$ until reaching an optical density of $\sim 1$ at $600 \mathrm{~nm}$. Cultures were induced by addition of $1 \mathrm{mM}$ IPTG, and $0.5 \mathrm{mM} \alpha$-aminolevulenic acid, a heme precursor, was added. The temperature was lowered to $30{ }^{\circ} \mathrm{C}$ for 24 (CYP102A1) or $48 \mathrm{~h}$ (CYP119). Following expression, cells were harvested by centrifugation, and cell pellets were stored at $-80{ }^{\circ} \mathrm{C}$ until needed.

Cell pellets were resuspended in cold wash buffer $(50 \mathrm{mM}$ Tris $\mathrm{pH} 8,300 \mathrm{mM}$ sodium chloride, $20 \mathrm{mM}$ imidazole). A small spatula tip of each of two protease inhibitors (benzamidine hydrochloride and Pefabloc SC) was added, and cells were lysed by two to three cycles of probe-tip sonication ( $0.5 \mathrm{~s}$ on, $0.5 \mathrm{~s}$ off, for $5 \mathrm{~min}$ ), cooled by an icewater bath. After centrifugation $\left(15000 \mathrm{rpm}, 1 \mathrm{~h}, 8^{\circ} \mathrm{C}\right)$ to pellet cellular debris, the supernatant was loaded directly onto a $\mathrm{Ni}$ batch column. After thorough washing with wash buffer (1.5-2 L), protein was eluted $(200 \mathrm{mM}$ imidazole in wash buffer), and the colored (red/orange) fractions were collected and concentrated in $30 \mathrm{kDa}$ centrifugal filters. Gel filtration chromatography was used to remove fragmented proteins, followed by buffer exchange into $20 \mathrm{mM}$ Tris, $\mathrm{pH} 8$, with 20 $\mathrm{mM}$ dithiothreitol (DTT) added to reduce intermolecular disulfide bonds. Purity was determined by UV-vis absorption $\left(A_{420} / A_{280}\right)$, SDS-PAGE, and mass spectrometry. Protein not intended for immediate use was flash-frozen in liquid nitrogen (with $40 \%$ glycerol added to solution as cryoprotectant) and stored at $-80{ }^{\circ} \mathrm{C}$.

Conjugation to Ru-Photosensitizer. An approximately 3fold excess of $\left[\mathrm{Ru}(\mathrm{bpy})_{2}(\mathrm{IA}-\mathrm{phen})\right]^{2+}$ was added to a $\sim 10 \mu \mathrm{M}$ solution of $\mathrm{P} 450$ mutant in $20 \mathrm{mM}$ Tris buffer $(\mathrm{pH} 8)$ and shaken in the dark at $4{ }^{\circ} \mathrm{C}$. Labeling progress can be monitored by MALDI mass spectrometry; no further increase in the peak corresponding to the predicted mass of $\mathrm{Ru}^{2+}-\mathrm{P} 450$ was observed after $2 \mathrm{~h}$. Excess $\left[\mathrm{Ru}(\text { bpy })_{2}(\mathrm{IA} \text {-phen })\right]^{2+}$ was removed during concentration in $30 \mathrm{kDa}$ filters, followed by desalting on an FPLC HiPrep column.

To separate photosensitizer-labeled and unlabeled enzymes, protein samples were loaded onto an anion exchange MonoQ or HiPrep Q column equilibrated with $20 \mathrm{mM}$ Tris buffer, $\mathrm{pH} 8$ ( $Q$ wash buffer). The column was washed with $Q$ wash buffer until UV-visible absorbance returned to baseline. The gradient was ramped quickly to $59 \%$ Q elution buffer (Q wash buffer + $250 \mathrm{mM}$ sodium chloride), followed by a slow gradient of 59$65 \%$ Q elution buffer over $60 \mathrm{~min}$. Successful conjugation and separation of $\mathrm{Ru}-\mathrm{P} 450$ was verified by $\mathrm{UV}-$ vis, mass spectrometry, and fluorometry.

Laser Spectroscopy Sample Preparation. Laser samples were composed of $\sim 10 \mu \mathrm{M} \mathrm{Ru}-\mathrm{P} 450$ conjugate, with and without oxidative quencher $\left(17 \mathrm{mM}\left[\mathrm{Ru}\left(\mathrm{NH}_{3}\right)_{6}\right] \mathrm{Cl}_{3}\right)$ or reductive quencher (10 $\mathrm{mM} p \mathrm{MeODMA})$ in buffered solution ( $\mathrm{pH} 8,50 \mathrm{mM}$ sodium borate or $50 \mathrm{mM}$ Tris); additionally, each buffer contained sodium chloride to prevent precipitation. pMeODMA is only sparingly soluble in water; aqueous stock solutions were prepared by dropwise addition of concentrated pMeODMA/DMSO solution into aqueous buffer $(50 \mathrm{mM}$ sodium borate, $\mathrm{pH} 8$ ). Fresh $p \mathrm{MeODMA}$ solutions were prepared immediately prior to use and protected from light, as oxygenated solutions change from clear to pinkish/purple in ambient light. Laser samples were placed in a high-vacuum four-sided quartz fluorescence cuvette with high-vacuum Teflon valve, equipped with a small stir bar. Deoxygenation was achieved via $3 \times 10-15$ gentle pump-backfill cycles with argon on a Schlenk line, with 15 min of equilibration between each set of cycles. Additional details provided in Supporting Information.

For nanosecond-to-millisecond transient luminescence and absorption experiments, excitation was provided by $480 \mathrm{~nm}$ pulses from a tunable optical parametric oscillator (Spectra Physics, Quanta-Ray MOPO-700) pumped by the third harmonic from a Spectra Physics Q-switched Nd:YAG laser (Spectra-Physics, Quanta-Ray PRO-Series, 8 ns pulse width) operated at $10 \mathrm{~Hz}$. Probe light was provided by a $75-\mathrm{W}$ arc lamp (PTI model A 1010) that could be operated in continuous or pulsed mode and passed through the sample collinearly with the excitation pulse. After rejection of scattered light by appropriate long- and short-pass filters, and intensity modulation by a neutral density filter, probe wavelengths were 
Table 1. Luminescence Decay Times of Four Ru-P450 Conjugates in the Absence and Presence of Quenchers ${ }^{a}$

\begin{tabular}{|c|c|c|c|c|}
\hline enzyme & quencher & $\tau_{\text {mono, }} \mathrm{ns}$ & $\tau_{\mathrm{a}}, \mathrm{ns}\left(\rho_{\mathrm{a}}\right)$ & $\tau_{\mathrm{b}}$, ns $\left(\rho_{\mathrm{b}}\right)$ \\
\hline \multirow[t]{3}{*}{$\mathrm{Ru}_{\mathrm{C} 97}(\mathrm{CYP} 102 \mathrm{A1}) \mathrm{W} 96$} & none & 140 & $190(0.65)$ & $52(0.35)$ \\
\hline & {$\left[\mathrm{Ru}\left(\mathrm{NH}_{3}\right)_{6}\right]^{3+}$} & 30 & & \\
\hline & $p$ MeODMA & 62 & & \\
\hline \multirow[t]{3}{*}{$\mathrm{Ru}_{\mathrm{C} 97}(\mathrm{CYP} 102 \mathrm{Al}) \mathrm{W} 96 \mathrm{H}$} & none & 180 & $160(0.80)$ & $310(0.20)$ \\
\hline & {$\left[\mathrm{Ru}\left(\mathrm{NH}_{3}\right)_{6}\right]^{3+}$} & 33 & & \\
\hline & $p$ MeODMA & 65 & & \\
\hline \multirow[t]{3}{*}{$\mathrm{Ru}_{\mathrm{C} 77}(\mathrm{CYP} 119) \mathrm{H} 76$} & none & 200 & $220(0.85)$ & $45(0.15)$ \\
\hline & {$\left[\mathrm{Ru}\left(\mathrm{NH}_{3}\right)_{6}\right]^{3+}$} & 91 & & \\
\hline & $p$ MeODMA & 54 & & \\
\hline \multirow[t]{3}{*}{$\mathrm{Ru}_{\mathrm{C} 77}(\mathrm{CYP} 119) \mathrm{H} 76 \mathrm{~W}$} & none & 130 & $91(0.75)$ & $320(0.25)$ \\
\hline & {$\left[\mathrm{Ru}\left(\mathrm{NH}_{3}\right)_{6}\right]^{3+}$} & 48 & & \\
\hline & pMeODMA & 50 & & \\
\hline
\end{tabular}

${ }^{a}$ Quenchers: $\left[\mathrm{Ru}\left(\mathrm{NH}_{3}\right)_{6}\right]^{3+}, 17 \mathrm{mM}$; $p$ MeODMA, $10 \mathrm{mM}$. The relative amplitudes of major $\left(\rho_{\mathrm{a}}\right)$ and minor $\left(\rho_{\mathrm{b}}\right)$ components in biexponential fits to the unquenched decays also are listed. Samples were excited at $480 \mathrm{~nm}$, and luminescence was detected at $630 \mathrm{~nm}$. Uncertainties in the decay times are $\pm 10 \%$, except for the single-exponential fits to the unquenched decays.

selected by a double monochromator (Instruments SA DH-10) with $1 \mathrm{~mm}$ slits. Transmitted light was detected by a photomultiplier tube (PMT, Hamamatsu R928) and amplified by a $200 \mathrm{MHz}$ wideband voltage amplifier DHPVA-200 (FEMTO).

Luminescence decays were monitored at $630 \mathrm{~nm}$. Single wavelength transient absorption kinetics were monitored every $10 \mathrm{~nm}$ from 390 to $440 \mathrm{~nm}$, averaging $\sim 500$ shots per wavelength. Data from five separate time scales $(2 \mu \mathrm{s}, 40 \mu \mathrm{s}$, $400 \mu \mathrm{s}, 10 \mathrm{~ms}$, and $500 \mathrm{~ms}$ ) were collected, log-compressed, and spliced together to produce full kinetics traces using Matlab software (Mathworks).

\section{RESULTS}

Ru-P450 Conjugates. Electron-transfer kinetics measurements were performed on four $\mathrm{Ru}-\mathrm{P} 450$ conjugates: two mutants of CYP102A1 and two of CYP119. The Ru-P450 from our previous work is a triple mutant of CYP102A1: C62A/C156S/K97C with $\left[\mathrm{Ru}\left(2,2^{\prime} \text {-bipyridine }\right)_{2}\right.$ (5-acetamido1,10-phenanthroline $)]^{2+}\left(\left[\mathrm{Ru}(\mathrm{bpy})_{2}(\text { APhen })\right]^{2+}\right)$ covalently bound to $\mathrm{C} 97$ via a thioether linkage $\left(\mathrm{Ru}_{\mathrm{C} 97}(\mathrm{CYP} 102 \mathrm{A1}) \mathrm{W} 96\right)$. To investigate the importance of W96 in photochemical ET, we generated the analogous conjugate with a $\mathrm{W} 96 \mathrm{H}$ mutation $\left(\mathrm{Ru}_{\mathrm{C} 97}(\mathrm{CYP} 102 \mathrm{A1}) \mathrm{W} 96 \mathrm{H}\right)$. The W96H mutation should preserve hydrogen-bonding with the heme propionates, which is thought to provide structural stability to the heme. ${ }^{40}$ But, unlike tryptophan, this side chain should not be susceptible to oxidation by photochemically generated $\mathrm{Ru}^{3+} \cdot{ }^{11}$

We have prepared analogous $\mathrm{Ru}-\mathrm{P} 450$ conjugates with an intervening histidine or tryptophan residue in thermophilic CYP119. The residue corresponding to CYP102A1-W96 is H76 in CYP119 (Figure 1); a cysteine mutation at residue 77 serves as the photosensitizer attachment point. The two $\mathrm{Ru}-$ CYP119 conjugates are referred to as $\mathrm{Ru}_{\mathrm{C} 77}(\mathrm{CYP} 119) \mathrm{H} 76$ and $\mathrm{Ru}_{\mathrm{C} 77}(\mathrm{CYP} 119) \mathrm{H} 76 \mathrm{~W}$.

Luminescence Quenching Measurements. The Ru(diimine) ${ }_{3}$ photosensitizer luminesces upon $480 \mathrm{~nm}$ excitation. The luminescence decay of all four $\mathrm{Ru}-\mathrm{P} 450$ conjugates is nonexponential, attributable to multiple photosensitizer conformations that do not exchange on the luminescence decay time scale. The nonexponential decay kinetics are most pronounced for mutants containing a tryptophan residue adjacent to the $\mathrm{Ru}$-tethering point $\left(\mathrm{Ru}_{\mathrm{C} 97}(\mathrm{CYP} 102 \mathrm{A1}) \mathrm{W} 96\right.$, $\left.\mathrm{Ru}_{\mathrm{C} 77}(\mathrm{CYP} 119) \mathrm{H} 76 \mathrm{~W}\right)$. The mild oxidant $\left[\mathrm{Ru}\left(\mathrm{NH}_{3}\right)_{6}\right]^{3+}$ is an efficient quencher of excited $\mathrm{Ru}$ (diimine) ${ }_{3}{ }^{2+}$ complexes $\left(* \mathrm{Ru}^{2+}\right),{ }^{35}$ producing powerfully oxidizing $\mathrm{Ru}(\text { diimine })_{3}{ }^{3+}$ in high yield. In the presence of $\left[\mathrm{Ru}\left(\mathrm{NH}_{3}\right)_{6}\right]^{3+}(17 \mathrm{mM})$, luminescence is strongly quenched, and the decay kinetics can be fit to a single exponential function (Table 1). There are small differences in quenched decay times; in particular, the decay time of quenched $\mathrm{Ru}_{\mathrm{C} 77}(\mathrm{CYP} 119) \mathrm{H} 76$ is approximately two to three times longer than that found in the three other proteins (90 ns vs $30-50 \mathrm{~ns}$ ). The origin of this difference is not readily apparent.

In prior work, we demonstrated that para-methoxy- $N, N$ dimethylaniline ( $p$ MeODMA) quenches $* \mathrm{Ru}^{2+}$ complexes to produce one-electron reduced forms $\left(\mathrm{Ru}^{+}\right) \cdot{ }^{39}$ In the presence of $10 \mathrm{mM}$ pMeODMA, $* \mathrm{Ru}^{2+}$ luminescence is efficiently quenched, and the decay kinetics are monoexponential. In contrast to the oxidative quenching with $\left[\mathrm{Ru}\left(\mathrm{NH}_{3}\right)_{6}\right]^{3+}$, there is very little difference in the quenched decay times among the four $\mathrm{Ru}-\mathrm{P} 450$ conjugates (Table 1 ).

Transient Absorption Measurements. In the absence of electron-transfer quenchers, the transient absorption features of the $\mathrm{Ru}-\mathrm{P} 450$ conjugates are characterized by a loss of $\mathrm{Ru}$ (diimine) ${ }_{3}{ }^{2+}$ metal-to-ligand charge transfer (MLCT) absorbance in the $400-440 \mathrm{~nm}$ region due to depopulation of the ground-state photosensitizer. The spectral and temporal profiles of these transients are essentially identical for the free photosensitizer and all four $\mathrm{Ru}-\mathrm{P} 450$ conjugates: the features return to baseline with the same time constants as the luminescence decay.

Oxidative Quenching. Transient absorption measurements demonstrate that $\left[\mathrm{Ru}\left(\mathrm{NH}_{3}\right)_{6}\right]^{3+}$ quenches the $* \mathrm{Ru}^{2+}$ to produce electron-transfer products (Figure 2). The ligand field absorption bands of $\left[\mathrm{Ru}\left(\mathrm{NH}_{3}\right)_{6}\right]^{3+/ 2+}$ are too weak to make any detectable contribution to the transient spectra. Photogenerated $\left[\mathrm{Ru}(\text { bpy })_{2}(\text { Aphen })\right]^{3+}\left(\mathrm{Ru}^{3+}\right)$ is characterized by a bleach of $\left[\mathrm{Ru}(\text { bpy })_{2} \text { (Aphen) }\right]^{2+}$ MLCT absorption between 390 and $440 \mathrm{~nm}$, and time-resolved absorption measurements reveal that it persists for several microseconds before reacting with $\left[\mathrm{Ru}\left(\mathrm{NH}_{3}\right)_{6}\right]^{2+}$ to regenerate the $\mathrm{Ru}^{2+}$ sensitizer and oxidized quencher (Figure 2).

We reported previously that when $\left[\mathrm{Ru}(\mathrm{bpy})_{2}(\mathrm{IAphen})\right]^{2+}$ is conjugated to $\mathrm{C} 97$ in $\mathrm{CYP} 102 \mathrm{A1}$, photogenerated $\mathrm{Ru}_{\mathrm{C} 97}{ }^{3+}$ (CYP102A1)W96 sequentially generates ferric-porphyrin radical cation $\left(\mathrm{Fe}^{3+}\right.$ por $\left.{ }^{\bullet+}\right)$ and $\mathrm{Fe}^{4+}$-hydroxide $\left(\mathrm{Fe}^{4+}-\mathrm{OH}\right.$, $\mathrm{CII})$ intermediates. These oxidation processes are characterized 


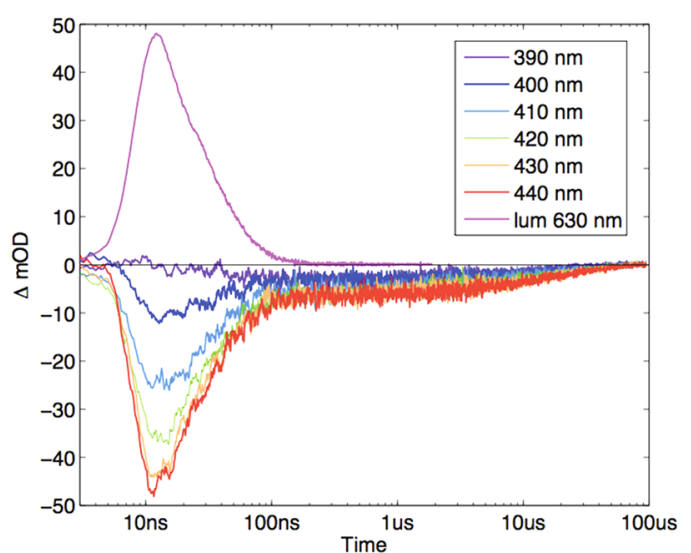

Figure 2. Transient absorption kinetics following $480 \mathrm{~nm}$ laser excitation of $\left[\mathrm{Ru}(\text { bpy })_{2}(\text { Aphen })\right]^{2+}$ in the presence of $\left[\mathrm{Ru}\left(\mathrm{NH}_{3}\right)_{6}\right]^{3+}$ $(17 \mathrm{mM})$. The purple curve is a luminescence decay trace.

by loss of absorbance at $420 \mathrm{~nm}$ (the peak of the $\mathrm{Fe}^{3+}-\mathrm{OH}_{2}$ heme Soret absorption) that persists for hundreds of milliseconds; formation of CII is characterized by the appearance of transient absorption at $440 \mathrm{~nm}$ on the millisecond time scale (Figure 3).

We subjected the other three $\mathrm{Ru}-\mathrm{P} 450$ conjugates to identical oxidative flash-quench irradiation and recorded the transient kinetics (Figure 3). The CYP119 mutant with an intervening tryptophan, $\mathrm{Ru}_{\mathrm{C} 77}(\mathrm{CYP} 119) \mathrm{H} 76 \mathrm{~W}$, displays transient absorption spectra and kinetics similar to those of $\mathrm{Ru}_{\mathrm{C} 97}(\mathrm{CYP} 102 \mathrm{A1}) \mathrm{W} 96$, albeit with smaller signal amplitudes $(<5 \mathrm{mOD})$ (Figure 3$)$. The lower ET yield in this variant may be a consequence of nonproductive oxidation of other nearby aromatic residues or less efficient competition with back electron transfer from reduced quencher. The results with $\mathrm{Ru}_{\mathrm{C} 97}(\mathrm{CYP} 102 \mathrm{~A} 1) \mathrm{W} 96$ and $\mathrm{Ru}_{\mathrm{C} 77}(\mathrm{CYP} 119) \mathrm{H} 76 \mathrm{~W}$ are in striking contrast to those of the $\mathrm{Ru}-\mathrm{P} 450$ constructs with an intervening histidine residue $\left(\mathrm{Ru}_{\mathrm{C} 97}(\mathrm{CYP} 102 \mathrm{~A} 1) \mathrm{W} 96 \mathrm{H}\right.$ and $\left.\mathrm{Ru}_{\mathrm{C} 77}(\mathrm{CYP} 119) \mathrm{H} 76\right)$. Neither of the latter constructs reveals any evidence indicative of heme oxidation following photochemical generation of the $\mathrm{Ru}$ (diimine) ${ }_{3}{ }^{3+}$ complex. In both cases, we observe only a bleach of the ground-state MLCT absorption features $(390-440 \mathrm{~nm})$ that returns to baseline within $200 \mu \mathrm{s}$. The spectral profiles and kinetics of these transients are nearly identical to that of the free photosensitizer $\left(\left[\mathrm{Ru}(\text { bpy })_{2}(\text { Aphen })\right]^{2+}\right.$ ) quenched with $\left[\mathrm{Ru}\left(\mathrm{NH}_{3}\right)_{6}\right]^{3+}$ (Figure $2)$. These observations suggest that $\mathrm{Ru}$ (diimine) ${ }_{3}{ }^{3+}$ oxidizes the P450 heme only in structures with an intervening tryptophan residue.

Reductive Quenching. Photochemical reduction of $\mathrm{Ru}-$ P450 conjugates was performed using $p M e O D M A$ as quencher. The resulting $\mathrm{Ru}^{+}$species has nearly $1 \mathrm{eV}$ of driving force for reduction of the ferric $\mathrm{P} 450$ heme: $E^{\circ}\left(\mathrm{Ru}(\mathrm{bpy}){ }_{3}{ }^{2+/+}=-1.3 \mathrm{~V}\right.$ vs $\mathrm{NHE} ;{ }^{33,34} E^{\circ}\left(\mathrm{P} 450 \mathrm{Fe}^{3+/ 2+}\right)=-0.43 \mathrm{~V}$ vs NHE. ${ }^{41}$ All four $\mathrm{Ru}-\mathrm{P} 450$ conjugates exhibit similar transient absorption features under flash-quench conditions (Figure 4). Three distinct kinetics phases appear on the nanosecond, microsecond, and millisecond time scales following pulsed laser excitation of the photosensitizer. All transient absorption features decay back to baseline within a few hundred milliseconds, suggesting that the overall photochemical process is reversible. The fastest kinetics phase $(\tau \approx 60 \mathrm{~ns})$ is assigned to decay of $* \mathrm{Ru}$ (diimine $)_{3}{ }^{2+}$; transient absorption features associated with this state decay with the same time constant as the luminescence. Transient absorption at $510 \mathrm{~nm}$, attributable

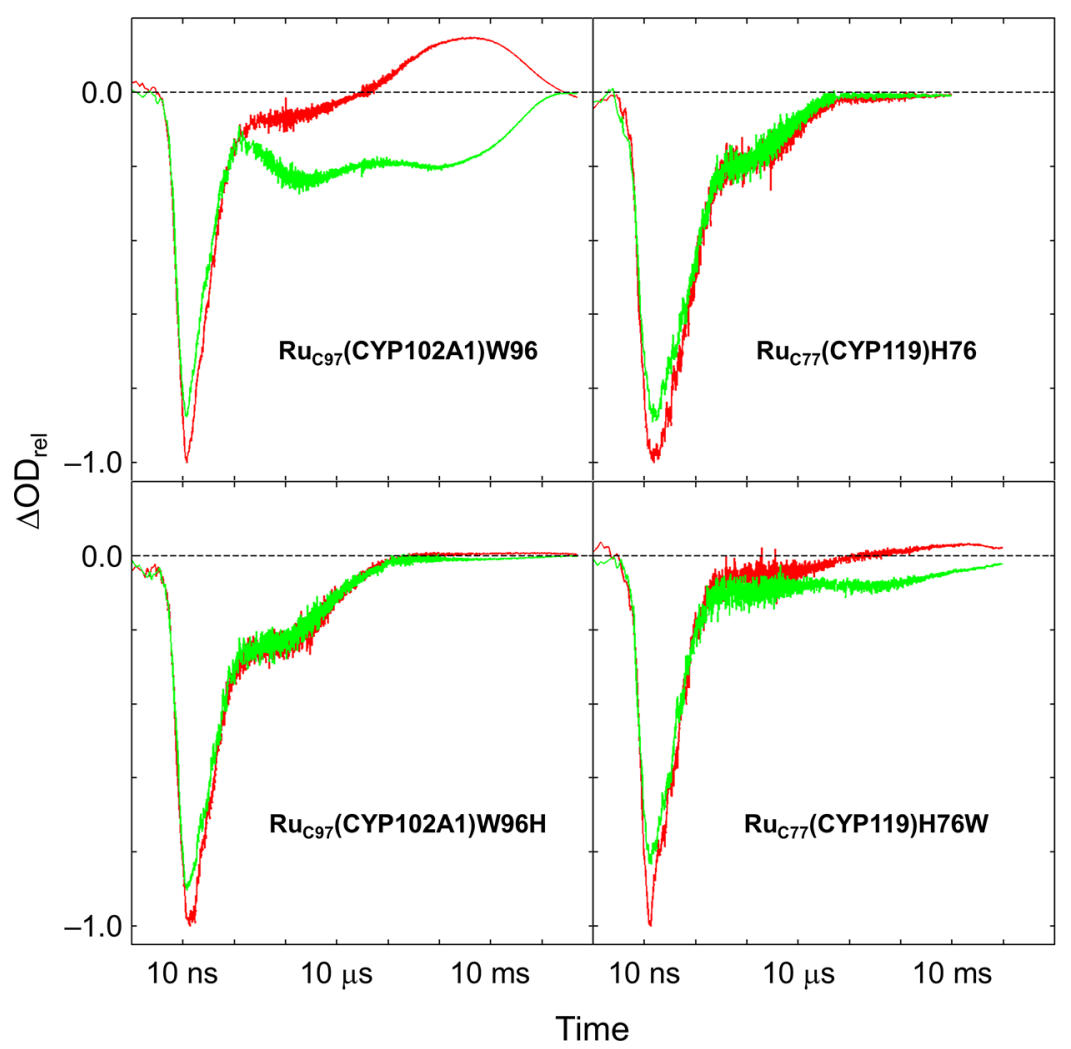

Figure 3. Transient kinetics following oxidative quenching $\left(\left[\mathrm{Ru}\left(\mathrm{NH}_{3}\right)_{6}\right]^{3+}, 17 \mathrm{mM}\right)$ in four $\mathrm{Ru}-\mathrm{P} 450$ conjugates: $\lambda_{\mathrm{ex}}=480 \mathrm{~nm} ; \lambda_{\text {obsd }}=420 \mathrm{~nm}$ (green), $440 \mathrm{~nm}$ (red). Signals normalized to the magnitude of the $440 \mathrm{~nm}$ prompt bleach. 


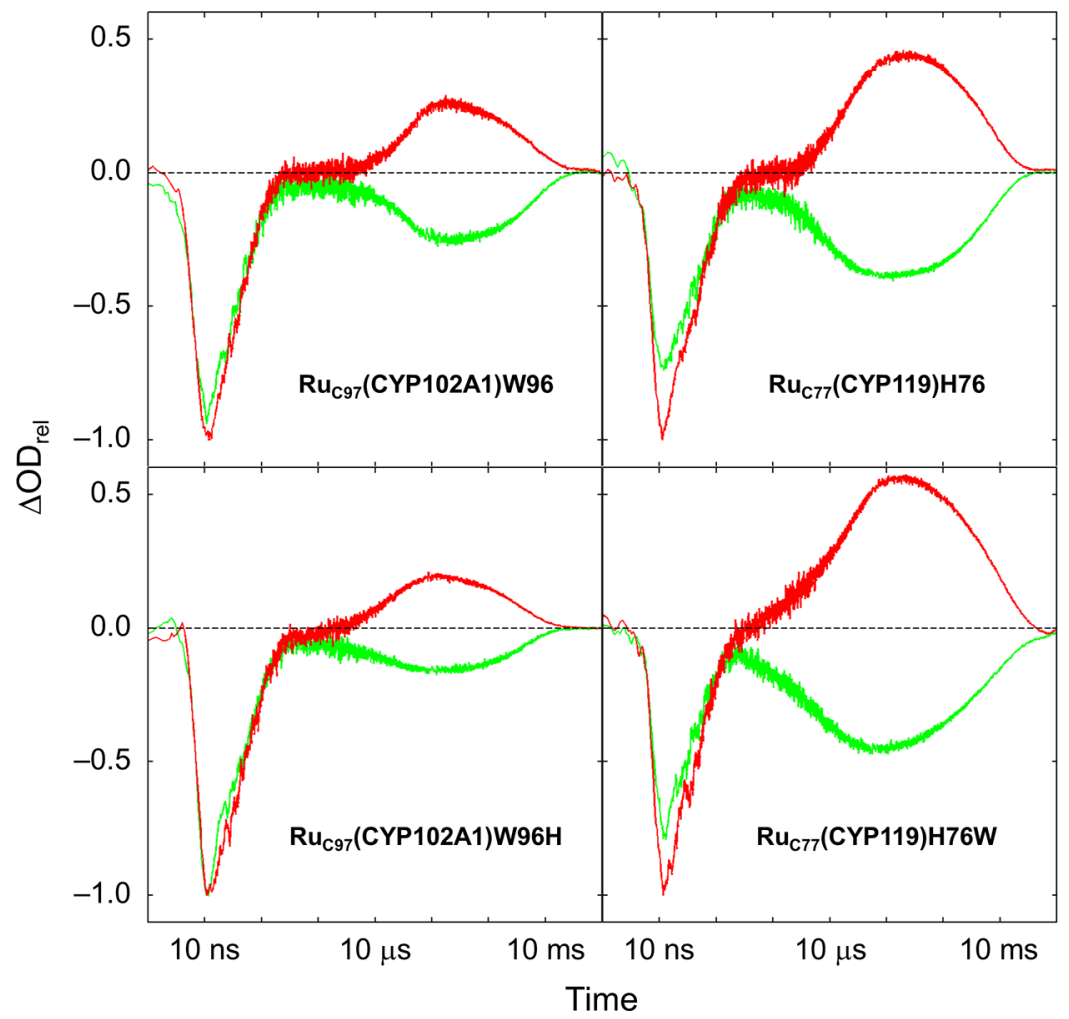

Figure 4. Transient kinetics following reductive quenching ( $p$ MeODMA, $10 \mathrm{mM}$ ) of four Ru-P450 conjugates: $\lambda_{\mathrm{ex}}=480 \mathrm{~nm} ; \lambda_{\mathrm{obsd}}=420 \mathrm{~nm}$ (green), $440 \mathrm{~nm}$ (red). Signals normalized to the magnitude of the $440 \mathrm{~nm}$ prompt bleach.

to $\mathrm{Ru}(\text { diimine })_{3}{ }^{+}$and $p \mathrm{MeODMA}^{\bullet+}$, develops with the same time constant. The subsequent microsecond kinetics phase is characterized by a bleach at $420 \mathrm{~nm}$ and increased absorbance at $440 \mathrm{~nm}$, indicative of a red-shift in the heme Soret band. In the resting state of $\mathrm{Fe}^{3+}-\mathrm{P} 450$, the Fe center is axially ligated by cysteine thiolate and water ligands, producing a low-spin electronic configuration. Chemical reduction of $\mathrm{Fe}^{3+}-\mathrm{P} 450$ produces a five-coordinate high-spin ferrous heme with a blueshifted Soret band. ${ }^{41}$ The red-shifted Soret observed following reductive quenching of the $\mathrm{Ru}-\mathrm{P} 450$ conjugates is indicative of a low-spin ferrous heme. ${ }^{42}$ The microsecond heme reduction by $\mathrm{Ru}^{+}$is likely faster than aquo ligand loss, resulting in a transient low-spin, six-coordinate ferrous species. This conclusion is consistent with the absorption profiles of $\mathrm{Fe}^{2+}(\mathrm{CO})-$ CYP101 ( $4450_{\text {cam }}$ from Pseudomonas putida), $\mathrm{Fe}^{2+}$ (imidazole)CYP101, and cryoreduced CYP101. ${ }^{43,44}$ The millisecond kinetics phase corresponds to reoxidation of the reduced heme by $p \mathrm{MeODMA}^{\circ+}$, resulting in a return to baseline of all transient absorption features and regeneration of $\mathrm{Fe}^{3+}\left(\mathrm{OH}_{2}\right)-$ P450 and $p$ MeODMA.

We performed a global least-squares analysis of the $\mathrm{Ru}-\mathrm{P} 450$ reductive quenching kinetics recorded at 420 and $440 \mathrm{~nm}$ (and, for select mutants, 400, 410, $430 \mathrm{~nm}$ ) to a three-exponential function with amplitude coefficients $\rho_{1-3}(\lambda)$ and rate constants $\gamma_{1-3}$ (eq 1). We fixed the first observed rate constant to the value obtained from single-exponential fits to the quenched luminescence decay kinetics recorded at $630 \mathrm{~nm}$. The remaining two rate constants, which were extracted from the global fitting, are listed in Table 2.

$$
\Delta \mathrm{OD}(\lambda, t)=\rho_{1}(\lambda) \mathrm{e}^{-\gamma_{1} t}+\rho_{2}(\lambda) \mathrm{e}^{-\gamma_{2} t}+\rho_{3}(\lambda) \mathrm{e}^{-\gamma_{3} t}
$$

The second rate constant corresponds to heme reduction. All four mutants exhibit very similar reduction rates, with
Table 2. Rate Constants for Ru-Sensitizer Quenching $\left(\gamma_{1}\right)$, Heme Reduction $\left(\gamma_{2}\right)$, and Heme Oxidation $\left(\gamma_{3}\right)$ Extracted from Global Fitting of Transient Absorption Data

\begin{tabular}{lccc}
\multicolumn{1}{c}{ enzyme } & $\gamma_{1}\left(\mathrm{~s}^{-1}\right)$ & $\gamma_{2}\left(\mathrm{~s}^{-1}\right)$ & $\gamma_{3}\left(\mathrm{~s}^{-1}\right)$ \\
$\mathrm{Ru}_{\mathrm{C} 97}($ CYP102A1)W96 & $1.6 \times 10^{7}$ & $3.6 \times 10^{4}$ & $1.1 \times 10^{2}$ \\
$\mathrm{Ru}_{\mathrm{C} 97}($ CYP102A1)W96H & $1.6 \times 10^{7}$ & $6.0 \times 10^{4}$ & $1.9 \times 10^{2}$ \\
$\mathrm{Ru}_{\mathrm{C} 77}($ CYP119)H76 & $1.9 \times 10^{7}$ & $5.7 \times 10^{4}$ & $1.4 \times 10^{2}$ \\
$\mathrm{Ru}_{\mathrm{C77}}($ CYP119)H76W & $1.9 \times 10^{7}$ & $8.1 \times 10^{4}$ & $1.3 \times 10^{2}$
\end{tabular}

maximum heme reduction complete at approximately $100 \mu \mathrm{s}$. Interestingly, after normalizing by the magnitude of the prompt $* \mathrm{Ru}^{2+}$ excited state bleach $(440 \mathrm{~nm})$, the magnitudes of the transient features associated with heme reduction (e.g., absorption at $440 \mathrm{~nm}$ ) differ greatly among the four $\mathrm{Ru}-$ P450 conjugates. In particular, both CYP119 mutants exhibit absorption features that are greater by a factor of $2-3$ than either of the CYP102A1 mutants (Figure 4).

All transient absorption features decay to baseline within 100 $\mathrm{ms}$; this return rate is extremely sensitive to small amounts of oxygen. In our proposed flash-quench scheme, reoxidation of the ferrous center occurs via bimolecular recombination with $p \mathrm{MeODMA}^{\bullet+}$. This recombination is expected to be a secondorder process; however, the disappearance of the transient features is better modeled as a first-order process, possibly owing to reaction with oxygen or minor impurities.

\section{DISCUSSION}

In a prior report on the kinetics of heme oxidation by $\mathrm{Ru}^{3+}$ in $\mathrm{Ru}_{\mathrm{C} 97}(\mathrm{CYP} 102 \mathrm{A1}) \mathrm{W} 96$, we found spectroscopic evidence for stepwise oxidation of $\mathrm{Fe}^{3+}\left(\mathrm{OH}_{2}\right)$-heme to $\mathrm{Fe}^{4+}(\mathrm{OH})$-heme via an intermediate porphyrin radical cation. Electron transfer from the porphyrin to $\mathrm{Ru}^{3+}{ }_{\mathrm{C} 97}$ was remarkably rapid $\left(8.5 \times 10^{5}\right.$ 
$\mathrm{s}^{-1}, \mathrm{pH} 8$ ), given the 20.8- $\AA$ distance from the $\mathrm{Ru}$-center to the nearest aromatic carbon atom on the porphyrin ring (Figure 5). ${ }^{35}$ This result conflicts with the semiclassical ET theory

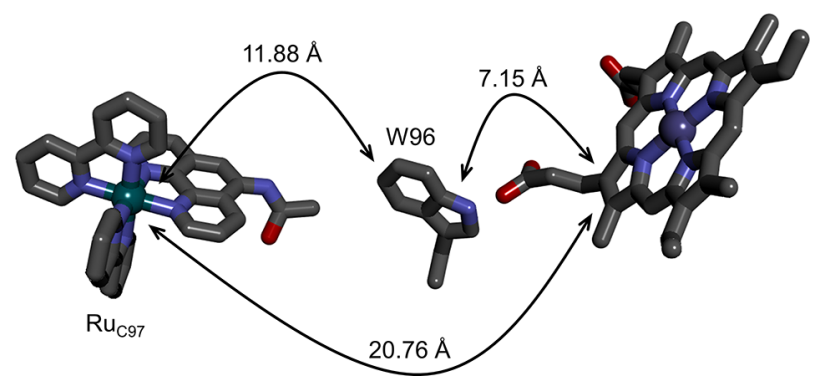

Figure 5. Structural model of $\mathrm{Ru}_{\mathrm{C} 97}-\mathrm{CYP} 102 \mathrm{Al}$ (PDB ID 3NPL) highlighting the electron-transfer distances from $\mathrm{Ru}_{\mathrm{C} 97}$ to the porphryin $(20.76 \AA), \mathrm{Ru}_{\mathrm{C} 97}$ to W96 (11.88 $\AA$ ), and W96 to the porphyrin $(7.15 \AA)$.

prediction that the rate constant for this reaction should be 3 orders of magnitude smaller $\left(4 \times 10^{2} \mathrm{~s}^{-1} ;-\Delta G^{\circ}=0.2 \mathrm{eV}\right.$; reorganization energy $\lambda=0.8 \mathrm{eV}$; distance decay factor $\beta=1.1$ $\AA^{-1}$, see Supporting Information). Indeed, the failure to observe flash-quench induced heme oxidation in $\mathrm{Ru}_{\mathrm{C} 77}(\mathrm{CYP} 119) \mathrm{H} 76$ is in better agreement with the slower predicted rate since porphyrin oxidation by $\mathrm{Ru}^{3+}$ apparently does not compete effectively with $\mathrm{Ru}^{3+}$ reduction by reduced quencher (complete in $100 \mu \mathrm{s})$.

The fact that we observe flash-quench heme oxidation only in $\mathrm{Ru}-\mathrm{P} 450$ s with intervening tryptophan residues strongly implicates the tryptophan radical cation as a reaction intermediate. Kinetics modeling of a stepwise hole-transfer reaction from $\mathrm{Ru}^{3+}$ to $\mathrm{W} 96^{\bullet+}$ to por ${ }^{\bullet+}$, using distances taken from the $\mathrm{Ru}_{\mathrm{C} 97}(\mathrm{CYP} 102 \mathrm{~A} 1) \mathrm{W} 96$ structure (PDB ID 3NPL) ${ }^{35}$ (Figure 5), predicts an apparent rate constant for porphyrin oxidation of $1.4 \times 10^{6} \mathrm{~s}^{-1}$ (Supporting Information), a value in remarkably good agreement with the experimentally derived quantity. The rate constant for hole transfer from $\mathrm{W} 96^{\circ+}$ to por $^{\bullet+}$ is predicted to be more than 2 orders of magnitude greater, suggesting that a negligibly small concentration of W96 $6^{\circ+}$ will build up during the porphyrin oxidation process (Figure 6).

The kinetics of the high-potential heme oxidation reaction are in striking contrast to those of the low-potential heme reduction reaction. The estimated driving force for the $\mathrm{Ru}^{+}$to $\mathrm{Fe}^{3+}\left(\mathrm{OH}_{2}\right)$-heme ET is $0.9 \mathrm{eV}$, close to the reorganization energy estimate of $0.8 \mathrm{eV}$. The ET distance is somewhat ambiguous for this reaction because the transferring electron could be localized on any one of the three diimine ligands. On the basis of the $\mathrm{Ru}_{\mathrm{C} 97}(\mathrm{CYP} 102 \mathrm{Al})$ crystal structure, ${ }^{35}$ the shortest distances from any diimine ligand to the Fe center range from 19.5 to $23.8 \AA$. Semiclassical ET theory predicts that the rate constant for reactions over this distance range will be $10^{3}-10^{5} \mathrm{~s}^{-1}$, in accord with the $\gamma_{2}$ values listed in Table 2 . Moreover, the rate constants for heme reduction vary by no more than a factor of 2 among the four conjugates. We conclude from this analysis that reduction of $\mathrm{Fe}^{3+}\left(\mathrm{OH}_{2}\right)$-heme by $\mathrm{Ru}_{\mathrm{C} 97}{ }^{+}$in CYP102A1 and by $\mathrm{Ru}_{\mathrm{C} 77}{ }^{+}$in CYP119 involves single step electron tunneling and that the intervening tryptophan (W96, W76) and histidine (H96, H76) residues serve only to mediate the superexchange coupling between the two redox sites (Figure 6).

The heme oxidation and reduction kinetics in $\mathrm{Ru}_{\mathrm{C} 97}(\mathrm{CYP} 102 \mathrm{A1})$ and $\mathrm{Ru}_{\mathrm{C} 77}(\mathrm{CYP} 119)$ highlight the asymmetry between high and low potential ET reactions in proteins. The electron-tunneling timetables extracted from our studies of ET in Ru-modified proteins provide benchmarks for single-step electron tunneling in which the reduction potential of the oxidant is $<1 \mathrm{~V}$ vs NHE. Our studies of $\mathrm{Ru}-\mathrm{P} 450$ clearly demonstrate that multistep tunneling reactions via tryptophan

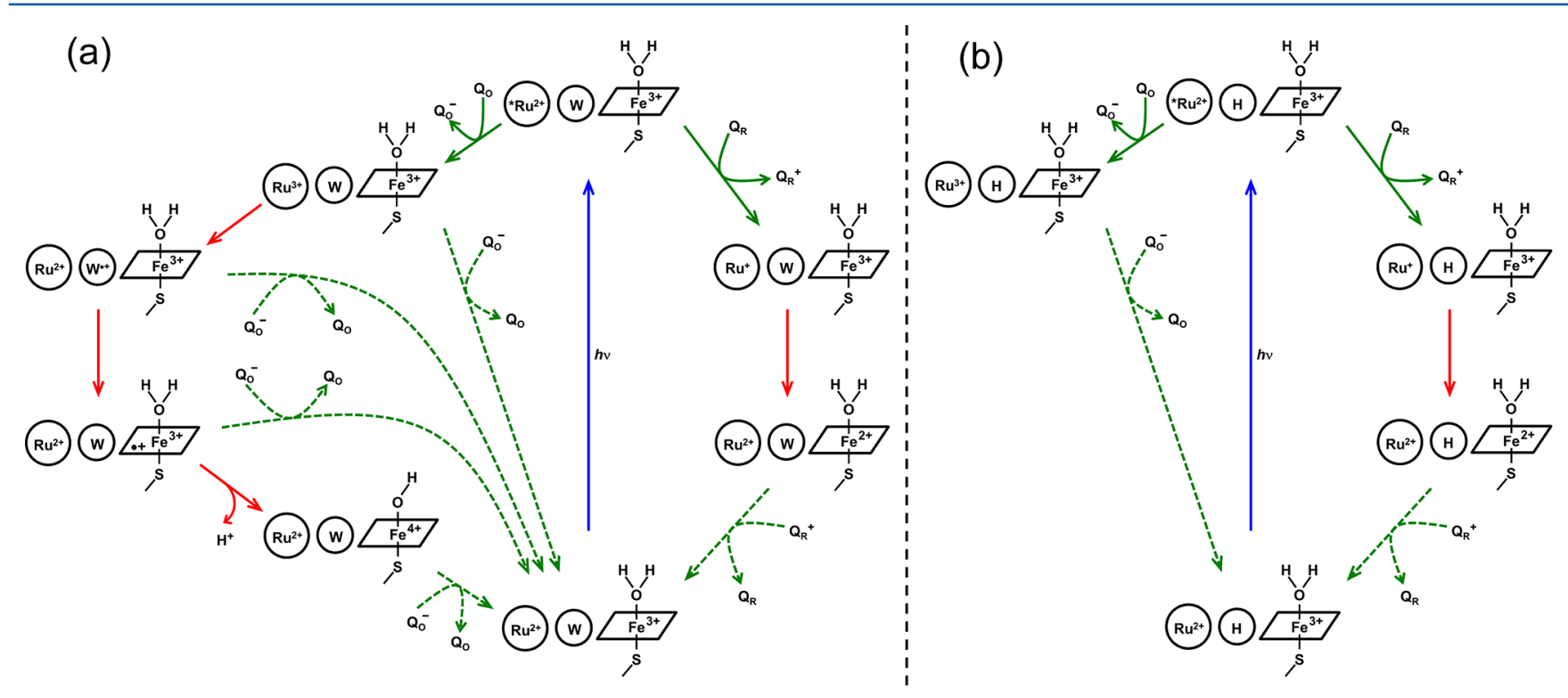

Figure 6. Photochemical ET reaction scheme in $\mathrm{Ru}_{\mathrm{C} 97}(\mathrm{CYP} 102 \mathrm{A1})$ and $\mathrm{Ru}_{\mathrm{C} 77}(\mathrm{CYP} 119)$. Blue arrows indicate excitation processes, solid green arrows indicate bimolecular quenching reactions, dashed green arrows indicate bimolecular charge-recombination processes with quencher redox products, and red arrows indicate intraprotein ET reactions. With an intervening W residue (a, CYP102A, W96; CYP119 H76W), oxidative quenching of $* \mathrm{Ru}^{2+}$ by $\mathrm{Q}_{0}$ (left path) leads to heme oxidation via an intermediate Trp radical; reductive quenching by $\mathrm{Q}_{\mathrm{R}}$ (right path) leads to heme reduction in a single-step tunneling reaction. With an intervening $\mathrm{H}$ residue (b, CYP102A, W96H; CYP119 H76), oxidative quenching of $* \mathrm{Ru}^{2+}$ by $\mathrm{Q}_{0}$ produces $\mathrm{Ru}^{3+}$ but not heme oxidation, whereas reductive quenching again leads to single-step electron transfer from $\mathrm{Ru}^{+}$to the heme. 
(and tyrosine) radicals come into play when oxidants have potentials $>1 \mathrm{~V}$. In addition, the radicals of the sulfurcontaining amino acids also might be participants in reactions with particularly high potential oxidants. For enzymes functioning with intermediates at potentials greater than $1 \mathrm{~V}$, protein structure and composition are critically important factors that ensure oxidizing equivalents are delivered to intended targets rather than diffusing to low potential sinks via multistep tunneling. The obvious corollary is that strategic placement of tryptophan and tyrosine residues in enzymes can direct the flow of oxidizing equivalents over long distances with little loss of potential.

\section{ASSOCIATED CONTENT}

\section{S Supporting Information}

The Supporting Information is available free of charge on the ACS Publications website at DOI: 10.1021/acs.biochem.7b00432.

Additional experimental details, spectra of ferric and ferrous wild-type P450-BM3 and the ferrous-ferric difference spectrum, details of electron transfer rate calculations, and estimated electron transfer rate constants (PDF)

\section{AUTHOR INFORMATION}

\section{Corresponding Authors}

*Harry B. Gray. E-mail: hbgray@caltech.edu. Phone: 626-3956500.

*Jay R. Winkler. E-mail: winklerj@caltech.edu. Phone: 626395-2834.

\section{ORCID}

Jay R. Winkler: 0000-0002-4453-9716

\section{Present Address}

${ }^{\dagger}$ M.E.E.: Department of Chemistry, Yale University, 225 Prospect St., P.O. Box 208107, New Haven, CT 06520, U.S.A.

\section{Funding}

Research reported in this publication was supported by the National Institute of Diabetes and Digestive and Kidney Diseases of the National Institutes of Health under Award Number R01DK019038. The content is solely the responsibility of the authors and does not necessarily represent the official views of the National Institutes of Health. Additional support was provided by the Arnold and Mabel Beckman Foundation.

\section{Notes}

The authors declare no competing financial interest.

\section{ABBREVIATIONS}

ET, electron transfer; MLCT, metal-to-ligand charge transfer; $\left[\mathrm{Ru}(\text { bpy })_{2}(\text { IAphen })\right]^{2+},\left[\mathrm{Ru}\left(2,2^{\prime} \text {-bipyridine }\right)_{2}\right.$ (5-iodoacetamido 1,10-phenanthroline $)]^{2+} ; \quad\left[\mathrm{Ru}(\mathrm{bpy})_{2} \text { (Aphen) }\right]^{2+}, \quad\left[\mathrm{Ru}\left(2,2^{\prime}\right.\right.$-bipyridine $)_{2}(5$-acetamido-1,10-phenanthroline $\left.)\right]^{2+} ; \quad$ MeODMA, p-methoxydimethylaniline

\section{REFERENCES}

(1) Heinze, J. (2016) Aliphatic and Aromatic Hydrocarbons Reduction, in Organic Electrochemistry (Hammerich, O., and Speiser, B., Eds.), pp 861-890, Taylor and Francis Group, Boca Raton, FL.

(2) Holton, D. M., Edwards, P. P., and Salmon, G. A. (1984) Electrons, alkali metal-electron species and radical anions in substituted organic amides. J. Phys. Chem. 88, 3855-3859.
(3) Knecht, L. A., and Kolthoff, I. M. (1962) N-Methylacetamide as a Polarographic Solvent. Inorg. Chem. 1, 195-203.

(4) Harriman, A. (1987) Further Comments on the Redox Potentials of Tryptophan and Tyrosine. J. Phys. Chem. 91, 6102-6104.

(5) Fourré, I., Bergès, J., and Houée-Levin, C. (2010) Structural and Topological Studies of Methionine Radical Cations in Dipeptides: Electron Sharing in Two-Center Three-Electron Bonds. J. Phys. Chem. A 114, 7359-7368.

(6) Glass, R. S., Hug, G. L., Schoneich, C., Wilson, G. S., Kuznetsova, L., Lee, T. M., Ammam, M., Lorance, E., Nauser, T., Nichol, G. S., and Yamamoto, T. (2009) Neighboring Amide Participation in Thioether Oxidation: Relevance to Biological Oxidation. J. Am. Chem. Soc. 131, 13791-13805.

(7) Glass, R. S., Petsom, A., Hojjatie, M., Coleman, B. R., Duchek, J. R, Klug, J., and Wilson, G. S. (1988) Facilitation of Electrochemical Oxidation of Dialkyl Sulfides Appended with Neighboring Carboxylate and Alcohol Groups. J. Am. Chem. Soc. 110, 4772-4778.

(8) Jovanovic, S. V., Harriman, A., and Simic, M. G. (1986) ElectronTransfer Reactions of Tryptophan and Tyrosine Derivatives. J. Phys. Chem. 90, 1935-1939.

(9) Surdhar, P. S., and Armstrong, D. A. (1987) Reduction potentials and exchange reactions of thiyl radicals and disulfide anion radicals. J. Phys. Chem. 91, 6532-6537.

(10) Yashiro, H., White, R. C., Yurkovskaya, A. V., and Forbes, M. D. E. (2005) Methionine radical cation: Structural studies as a function of $\mathrm{pH}$ using $\mathrm{X}$ - and Q-band time-resolved electron paramagnetic resonance spectroscopy. J. Phys. Chem. A 109, 5855-5864.

(11) Navaratnam, S., and Parsons, B. J. (1998) Reduction Potential of Histidine Free Radicals: a Pulse Radiolysis Study. J. Chem. Soc., Faraday Trans. 94, 2577-2581.

(12) Stubbe, J., and van der Donk, W. A. (1998) Protein Radicals in Enzyme Catalysis. Chem. Rev. 98, 705-762.

(13) Aubert, C., Mathis, P., Eker, A. P. M., and Brettel, K. (1999) Intraprotein Electron Transfer between Tyrosine and Tryptophan in DNA photolysase from Anacystis nidulans. Proc. Natl. Acad. Sci. U. S. A. 96, 5423-5427.

(14) Aubert, C., Vos, M. H., Mathis, P., Eker, A. P. M., and Brettel, K. (2000) Intraprotein Radical Transfer during Photoactivation of DNA Photolyase. Nature 405, 586-590.

(15) DeGray, J. A., Lassmann, G., Curtis, J. F., Kennedy, T. A., Marnett, L. J., Eling, T. E., and Mason, R. P. (1992) Spectral-Analysis of the Protein-Derived Tyrosyl Radicals from Prostaglandin-H Synthase. J. Biol. Chem. 267, 23583-23588.

(16) Eklund, H., Eriksson, M., Uhlin, U., Nordlund, P., and Logan, D. (1997) Ribonucleotide Reductase - Structural Studies of a Radical Enzyme. Biol. Chem. 378, 821-825.

(17) Goodin, D. B., Mauk, A. G., and Smith, M. (1986) Studies of the Radical Species in Compound ES of Cytochrome c Peroxidase Altered by Site-Directed Mutagenesis. Proc. Natl. Acad. Sci. U. S. A. 83, 12951299.

(18) Green, M. T. (1999) Evidence for Sulfur-Based Radicals in Thiolate Compound I Intermediates. J. Am. Chem. Soc. 121, 79397940.

(19) Licht, S., Gerfen, G. J., and Stubbe, J. A. (1996) Thiyl radicals in ribonucleotide reductases. Science 271, 477-481.

(20) Pogni, R., Baratto, M. C., Teutloff, C., Giansanti, S., RuizDueñas, F. J., Choinowski, T., Piontek, K., Martínez, A. T., Lendzian, F., and Basosi, R. (2006) A Tryptophan Neutral Radical in the Oxidized State of Versatile Peroxidase from Pleurotus eryngii: a Combined Multifrequency EPR and Density Functional Theory Study. J. Biol. Chem. 281, 9517-9526.

(21) Bernini, C., Pogni, R., Basosi, R., and Sinicropi, A. (2012) The nature of tryptophan radicals involved in the long-range electron transfer of lignin peroxidase and lignin peroxidase-like systems: Insights from quantum mechanical/molecular mechanics simulations. Proteins: Struct., Funct., Genet. 80, 1476-1483.

(22) Gray, H. B., and Winkler, J. R. (2015) Hole hopping through tyrosine/tryptophan chains protects proteins from oxidative damage. Proc. Natl. Acad. Sci. U. S. A. 112, 10920-10925. 
(23) Muller, P., Yamamoto, J., Martin, R., Iwai, S., and Brettel, K. (2015) Discovery and functional analysis of a 4th electron-transferring tryptophan conserved exclusively in animal cryptochromes and (6-4) photolyases. Chem. Commun. 51, 15502-15505.

(24) Winkler, J. R., and Gray, H. B. (2015) Electron flow through biological molecules: does hole hopping protect proteins from oxidative damage? Q. Rev. Biophys. 48, 411-420.

(25) Kathiresan, M., and English, A. M. (2017) LC-MS/MS suggests that hole hopping in cytochrome $\mathrm{c}$ peroxidase protects its heme from oxidative modification by excess $\mathrm{H} 2 \mathrm{O} 2$. Chem. Sci. 8, 1152-1162.

(26) Ortiz de Montellano, P. R., Ed. (2015) Cytochrome P450 Structure, Mechanism, and Biochemistry, Springer, Switzerland.

(27) Green, M. T., Dawson, J. H., and Gray, H. B. (2004) Oxoiron(IV) in Chloroperoxidase Compound II is Basic: Implications for P450 Chemistry. Science 304, 1653-1656.

(28) Behan, R. K., Hoffart, L. M., Stone, K. L., Krebs, C., and Green, M. T. (2006) Evidence for basic ferryls in cytochromes P450. J. Am. Chem. Soc. 128, 11471-11474.

(29) Krest, C. M., Onderko, E. L., Yosca, T. H., Calixto, J. C., Karp, R. F., Livada, J., Rittle, J., and Green, M. T. (2013) Reactive Intermediates in Cytochrome P450 Catalysis. J. Biol. Chem. 288, 17074-17081.

(30) Rittle, J., and Green, M. T. (2010) Cytochrome P450 Compound I: Capture, Characterization, and C-H Bond Activation Kinetics. Science 330, 933-937.

(31) Yosca, T. H., Rittle, J., Krest, C. M., Onderko, E. L., Silakov, A., Calixto, J. C., Behan, R. K., and Green, M. T. (2013) Iron(IV)hydroxide $\mathrm{pK}(\mathrm{a})$ and the Role of Thiolate Ligation in $\mathrm{C}-\mathrm{H}$ Bond Activation by Cytochrome P450. Science 342, 825-829.

(32) Modi, A. R., Dawson, J. H., Hrycay, E. G., and Bandiera, S. M. (2015) Oxidizing Intermediates in P450 Catalysis: A Case for Multiple Oxidants. Adv. Exp. Med. Biol. 851, 63-81.

(33) Sutin, N., and Creutz, C. (1978) Properties and Reactivities of the Luminescent Excited States of Polypyridine Complexes of Ruthenium(II) and Osmium(II), in Inorganic and Organometallic Photochemistry (Wrighton, M. S., Ed.), pp 1-27, American Chemical Society, Washington, DC.

(34) Creutz, C., Chou, M., Netzel, T. L., Okumura, M., and Sutin, N. (1980) Lifetimes, Spectra, and Quenching of the Excited-States of Polypyridine Complexes of Iron(II), Ruthenium(II), and Osmium(II). J. Am. Chem. Soc. 102, 1309-1319.

(35) Ener, M. E., Lee, Y. T., Winkler, J. R., Gray, H. B., and Cheruzel, L. (2010) Photooxidation of cytochrome P450-BM3. Proc. Natl. Acad. Sci. U. S. A. 107, 18783-18786.

(36) Girvan, H. M., Seward, H. E., Toogood, H. S., Cheesman, M. R., Leys, D., and Munro, A. W. (2007) Structural and spectroscopic characterization of P450BM3 mutants with unprecedented P450 heme iron ligand sets - New heme ligation states influence conformational equilibria in P450BM3. J. Biol. Chem. 282, 564-572.

(37) Park, S.-Y., Yamane, K., Adachi, S.-i., Shiro, Y., Weiss, K. E., Maves, S. A., and Sligar, S. G. (2002) Thermophilic cytochrome P450 (CYP119) from Sulfolobus solfataricus: high resolution structure and functional properties. J. Inorg. Biochem. 91, 491-501.

(38) Castellano, F. N., Dattelbaum, J. D., and Lakowicz, J. R. (1998) Long-lifetime $\mathrm{Ru}(\mathrm{II})$ complexes as labeling reagents for sulfhydryl groups. Anal. Biochem. 255, 165-170.

(39) Mines, G. A., Bjerrum, M. J., Hill, M. G., Casimiro, D. R., Chang, I.-J., Winkler, J. R., and Gray, H. B. (1996) Rates of Heme Oxidation and Reduction in $\mathrm{Ru}($ His 33)cytochrome $c$ at Very High Driving Forces. J. Am. Chem. Soc. 118, 1961-1965.

(40) Munro, A. W., Malarkey, K., McKnight, J., Thomson, A. J., Kelly, S. M., Price, N. C., Lindsay, J. G., Coggins, J. R., and Miles, J. S. (1994) The Role of Tryptophan-97 of Cytochrome P450-BM3 from Bacillus megaterium in Catalytic Function - Evidence Against the Covalent Switching Hypothesis of P450 Electron Transfer. Biochem. J. 303, 423-428.

(41) Coelho, P. S., Wang, Z. J., Ener, M. E., Baril, S. A., Kannan, A., Arnold, F. H., and Brustad, E. M. (2013) A serine-substituted P450 catalyzes highly efficient carbene transfer to olefins in vivo. Nat. Chem. Biol. 9, 485-487.

(42) Whited, C. A., Belliston-Bittner, W., Dunn, A. R., Winkler, J. R., and Gray, H. B. (2009) Nanosecond photoreduction of inducible nitric oxide synthase by a $\mathrm{Ru}$-diimine electron tunneling wire bound distant from the active site. J. Inorg. Biochem. 103, 906-911.

(43) Dunn, A. R., Dmochowski, I. J., Winkler, J. R., and Gray, H. B. (2003) Nanosecond Photoreduction of Cytochrome P450cam by Channel-Specific Ru-Diimine Electron Tunneling Wires. J. Am. Chem. Soc. 125, 12450-12456.

(44) Denisov, I. G., Makris, T. M., and Sugar, S. G. (2002) Cryoradiolysis for the Study of P450 Reaction Intermediates. Methods Enzymol. 357, 103-115. 